\title{
PENANGANAN PENGEMBALIAN KEPERCAYAAN INVESTOR MELALUI MANAJEMEN KRISIS OLEH BADAN PENGUSAHAAN BATAM
}

\author{
Tria Dara Barlian, Hanny Hafiar, Diah Fatma S \\ Program Studi Hubungan Masyarakat, Fakultas Ilmu Komunikasi, \\ Universitas Padjadjaran \\ hannyhafiar@gmail.com
}

\begin{abstract}
As of the biggest tax report contributor in Indonesia, Batam is one of the advance city, but Batam is not guaranteed free from obstacles and barriers which blocked the investment activity in Batam. This obstacle inter alia is a lot of demonstration activity in Batam. Those protesters wreck the public facilities, main road, police office, and the investor's company. These anarchy activities make the investor become worried and questioning BP Batam effort to handle this situation. BP Batam already did some effort to muffle the demonstration that happen in Batam but the demonstration is still going on until now.

That's why researcher choose topic. The focus on the study: How's the Crisis Management on the Handling of Demonstration Issue Among Investor by the Batam Indonesia Free Zone Authority.

This research used qualitative approach with the constructivism paradigm and case study form of study. The subjects were BP Batam officials. Data were collected through in depth interview, passive participant observation, literature study, documenter study, and online data tracing. Using symbolic interactionism as theory by George Herbert Mead.

The result of this research revealed that issue management aspect which is conducted by the Batam Indonesia Free Zone Authority when demonstration strike for investor, first BIFZA will call the authority to execute securing vital objects. After that BIFZA will give information through online media and offline media. The next step is BIFZA organize a business gathering and invite foreign investor and local investor to deliver information related to demonstrations and finally investor gain information about demonstration and BIFZA effort to manage it. The communication pattern that the Batam Indonesia Free Zone Authority did to handle demonstration issue were interacting with it's public.
\end{abstract}

Keywords: Crisis Management, Investor relations, BIFZA

\section{PENDAHULUAN}

Batam di dalam melakukan kegiatan investor relations tidak terlepas dari sebuah isu yang sudah berkembang semenjak awal tahun 2011. Pada waktu itu terjadi demo besar-besaran yang dilakukan oleh Serikat Pekerja Seluruh Indonesia (SPSI) Kota Batam. SPSI melakukan aksi unjuk rasa di PT McDermott Indonesia, Batu Ampar, Sabtu 11 Juni 2011. Unjuk rasa itu digelar atas Pemutusan Hubungan Kerja (PHK) yang dilakukan perusahaan terhadap Ketua PUK SPSI PT McDermott, Sarif Ilyas. Sempat terjadi isu hangat yang berkembang, bahwa PT McDermott diisukan hengkang dari Batam. Seorang manajer di perusahaan itu yang tidak ingin namanya disebutkan mengatakan manajemen sempat membicarakan rencana relokasi ke Johor, Malaysia. Namun PT 
McDermott Indonesia tetap memutuskan menjalankan kegiatan usahanya di Batam sampai saat ini.

Menurut media lokal Haluan Kepri , pada salah satu kegiatan demonstrasi yang sedang berlangsung pada tahun 2011 tersebut membuat situasi Kota Batam menjadi mencekam dikarenakan sejumlah aksi anarkisme yang terjadi disejumlah titik. Kegiatan demonstrasi di Batam tidak hanya sekali saja terjadi, ada puluhan hingga ratusan demo yang terjadi. Isu-isu demonstrasi tersebut sempat beberapa kali masuk dalam pemberitaan nasional. Dan hal ini menyebabkan citra Batam sempat menjadi daerah yang tidak aman untuk melakukan kegiatan investasi.

Isu-isu demonstrasi tersebut telah berkembang semenjak tahun 2011 dan belum berhasil dikelola, pada akhirnya situasi ini menjadi krisis karena menghasilkan situasi yang tidak stabil dengan berbagai kemungkinan menghasilkan hasil yang tidak diinginkan yang menimbulkan kepanikan dari para investor yang berada di Batam dan menyebabkan investor menjadi ketakutan untuk menanamkan modalnya di Batam.

Usaha manajemen isu yang dilakukan oleh BP Batam belum berhasil maka muncullah kegiatan manajemen krisis yang merupakan hasil dari ketidak berhasilan dalam mengelola isu demonstrasi melebar menjadi krisis ini. Isu demonstrasi di Batam perlu ditangani karena meneror kognitif dari investor. Tugas BP Batam menarik karena BP Batam hanyalah satu-satunya badan yang berkembang di Indonesia yang bergerak langsung di dalam kegiatan melayani investor di suatu daerah.
Berpijak kepada uraian tersebut di atas, kasus yang dihadapi BP Batam adalah BP Batam berusaha menerangkan kepada investor bahwa isu demonstrasi yang terjadi bukanlah menjadi suatu momok yang menakutkan, hal ini menjadi rawan apabila isu ini di blow up oleh oknum-oknum tertentu maka reputasi yang dimiliki oleh wilayah Batam menurun dan investor akan kehilangan kepercayaannya kepada Batam dan menyebabkan Batam kehilangan pendapatan dan berpengaruh kepada pendapatan visa negara.

Oleh karena itu, tujuan dari penelitian ini adalah untuk mengetahui pola komunikasi yang dilakukan Badan Pengusahaan Kawasan Perdagangan dan Pelabuhan Bebas Batam untuk menanggulangi Isu Demonstrasi dalam kegiatan Investor Relations.

\section{TINJAUAN PUSTAKA}

\section{Manajemen Isu}

Definisi detail tentang manajemen isu diberikan oleh Coates, Coates, Jarrat and Heinz (dalam Kriyantono, 2012:162) manajemen isu adalah aktivitas yang diorganisasi (dalam suatu organisasi) untuk mengidentifikasi munculnya kecenderungan-kecenderungan (situasi) atau isu-isu yang dimungkinkan (diprediksi) memengaruhi aktivitas organisasi dalam beberapa tahun ke depan (termasuk dalam jangka pendek) dan membangun strategi organisasi untuk meresponnya. Pada masa lalu, banyak organisasi yang terlambat dalam mengidentifikasi dan merespons isu, bahkan kebanyakan responsnya lebih bersifat reaktif (bukan preventif/proaktif). (Kriyantono, 2012:162) 
Perlu dicatat bahwa manajemen isu dan manajemen krisis adalah dua hal yang berbeda tetapi saling berhubungan. Manajemen isu dilakukan sebagai antisipasi sebelum terjadinya krisis dan tetap harus dilakukan ketika krisis berlangsung. Berdasarkan pernyataan Gaunt \& Ollen Burger (1995 dalam Kriyantono, 2012:164) dan Regester \& Larkin (2008 dalam Kriyantono, 2012:164), dapat disimpulkan bahwa dalam manajemen isu, organisasi dituntut lebih proaktif untuk mengidentifikasi isu. Hasil identifikasi ini menjadi dasar untuk:

a. Menentukan strategi untuk merespons isu sebelum isu berkembang menjadi krisis yang mempunyai dampak bagi organisasi. Menanggapi isu ini termasuk menanggapi kritikan-kritikan dari pihak di luar organisasi. Howard Chase (1984, dikutip di Regester \& Larkin, 2008:41 dalam Kriyantono, 2012:162) menyatakan "organisasi harus bergerak dari information base (sekedar memberi informasi) menuju advocacy position (mempertahankan posisi dengan menjawab kritikan) karena organisasi bukan the silent children of society. Salah satunya melalui advocacy advertising. "Selanjutnya, beberapa kemungkinan atau faktor-faktor yang memicu ketidakpuasan publik mesti ditangani sedini mungkin dengan cara mengidentifikasi penyebab ketidakpuasan dan memberikan perhatian penuh pada isu tersebut sebelum berkembang luas menjadi perhatian publik. Tymson, dkk (2004:390 dalam Kriyantono, 2012:162) menyebut: "The best way to manage crisis is to understand and manage issues".

b. Mencari peluang untuk reposisi organisasi dan produk. Artinya, organisasi mencari isu-isu apa yang dapat menjadi peluang pasar meningkatkan penjualan dan reputasi. Misalnya, isu-isu kesehatan dan pendidikan murah adalah isu yang potensial eksis, jika dikelola akan dapat menjadi peluang positif mencari keuntungan. Perusahaan dapat memproduksi produk yang ramah lingkungan, program beasiswa atau CSR di bidang kesehatan.

Reaksi manajemen isu yang efektif didasarkan pada bagaimana mengidentifikasi isu di awal perkembangannya dan memberikan reaksi yang terorganisir dalam upaya menangani isu yang beredar di wilayah publik. Hal yang harus diingat adalah bahwa mengelola isu seharusnya tidak dianggap sebagai kegiatan defensif. Sifat manajemen isu sejatinya adalah proaktif, antisipatoris, dan terencana. Dirancang untuk mempengaruhi perkembangan sebuah isu, sebelum isu tersebut berkembang ke tahap serius yang membutuhkan manajemen krisis. (Nova, 2011:279)

Manejemen isu strategis adalah tanggung jawab seluruh organisasi. Tanggung jawab tersebut melintasi semua unit kerja. Kerangka kerja manajemen isu melibatkan tiga fungsi, yaitu:

1) Pengumpulan/pemantauan inteligen dan informasi;

2) Menganalisis informasi dan mengelompokkan masalah (issue classification); dan 
3) Mengambil tindakan dan mengevaluasi hasil (taking action and evaluating the results). (Nova, 2011:283)

Proses manajemen isu adalah proses mengidentifikasi dan memecahkan masalah dalam suatu organisasi. Menggunakan proses manajemen isu, kita dapat mengidentifikasi dan menyelesaikan masalah dengan cepat, sebelum isu memiliki dampak yang tidak diinginkan. (Nova, 2011:284)

Proses manajemen isu ini akan membantu untuk:

1) Mengidentifikasi isu

2) Menentukan dampak dari tiap isu

3) Membuat prioritas isu dan melaporkan status perkembangan isu

4) Meninjau semua masalah dan memutuskan suatu tindakan

5) Mengambil langkah yang diperlukan untuk menyelesaikan masalah dengan cepat (Nova, 2011:284)

Proses manajemen isu merupakan satu set prosedur yang membantu perusahaan mengelola masalah-malasah yang terjadi. Masalah akan selalu terjadi dan dapat memengaruhi kemampuan dan tujuan perusahaaan. Saat itulah proses manajemen isu menjadi sangat berharga. Sebuah proses isu membantu peneliti merekam setiap masalah dan mengidentifikasi tindakan yang diperlukan untuk menyelesaikannya. Sebagai bagian dari proses manajemen isu, langkah persetujuan dimaksud untuk memastikan bahwa tindakan yang tepat diambil, pada saat yang tepat. Proses manajemen isu digunakan ketika perusahaan mengalami masalah yang perlu diselesaikan dengan cepat. Gambar berikut ini menjelaskan proses tersebut. (Nova, 2011:284)
Secara umum, ada lima tahap aktivitas manajemen isu. Kelima tahap itu adalah:

1. Identifikasi Isu; Tujuan utama diidentifikasi isu adalah menempatkan prioritas awal atas berbagai isu yang mulai muncul.

2. Analisis Isu; Analisisi isu menentukan isu berdasarkan urgensinya dan dampaknya. Hal ini memungkinkan perusahaan dapat membedakan antara isu-isu kecil dan isu-isu besar. Jenis isu dapat dibuatkan rangking berdasarkan urgensi dan dampaknya terhadap perusahaan.

3. Pilihan Strategi Perubahan Isu; Ini merupakan tahap yang melibatkan pembuatan keputusan-keputusan dasar tentang respons organisasi.

4. Program Penanganan Isu; Pada fase ini organisasi harus memutuskan kebiijakan yang mendukung perubahan yang diinginkan untuk membuat program penanganan isu. Tahap ini membutuhkan koordinasi sumber daya untuk menyediakan dukungan yang optimal agar tujuan dan target dapat tercapai.

5. Evaluasi Hasil; Setelah semua tahapan di atas, akhirnya, dibutuhkan sebuah riset untuk mengevaluasi bagaimana implementasi program yang dilakukan. Semakin lama isu berkembang, semakin sedikit pilihan yang tersedia dan semakin mahal biayanya (Register \& Larkin, 2003 dalam Nova, 2011:289).

\section{METODE PENELITIAN}

Metode yang digunakan dalam penelitian ini adalah studi kasus dengan data yang bersifat kualitatif. Penelitian 
kualitatif dimaksudkan untuk memahami arti atau mencari makna dari peristiwa dan kaitan-kaitannya dengan orang-orang biasa dalam situasi tertentu (Moleong, 2013:9). Esensinya, penelitian kualitatif bertujuan menafirkan fenomena yang terjadi dan dilakukan dengan jalan melibatkan berbagai metode pada manajemen BP Batam, yang berkaitan dengan investor relations dan dalam upaya manajemen krisis mengenai isu demonstrasi.

Penelitian ini menggunakan desain studi kasus tunggal dengan tipe holistik. Penelitian studi kasus menempatkan sebuah kasus sebagai fokus dari penelitian dengan menggunakan berbagai sumber data. Penelitian ini pun menggunakan berbagai sumber informasi yang meliputi: observasi, wawancara, materi audio-visual, dokumentasi dan penelusuran online.

Dalam penelitian ini menggunakan tipe studi kasus eksploratoris karena gagasan penelitan Manajemen Krisis mengenai Isu Demonstrasi di Kalangan Investor oleh BP Batam ini diusung berdasarkan pengumpulan data yang dilakukan peneliti mengenai proses investor relations yang dilakukan untuk memperoleh kepercayaan investor kembali.

\section{HASIL PENELITIAN DAN PEMBAHASAN}

Berdasarkan hasil wawancara diketahui bahwa pola komunikasi yang dilakukan Badan Pengusahaan Kawasan Perdagangan dan Pelabuhan Bebas Batam untuk menanggulangi Isu Demonstrasi dalam kegiatan Investor Relations antara lain :

\section{Media}

Membuat sosialisai baik kepada media baik di dalam media online maupun media offline untuk menyampaikan hal-hal yang perlu disampaikan berkaitan dengan isu tersebut sehingga terjadinya demonstrasi. BP Batam mengeluarkan dana untuk biaya publikasi sebesar 1.3 Miliar untk berkerja sama dengan 11 media local. BP Batam juga melakukan klarifikasi jika terjadinya kesalahan pemberitaan maka pihak BP Batam akan melakukan hak jawab sesuai dengan prosedur, kemudian hak jawab itu ditembuskan ke Dewan Pers dan disesuaikan dengan ranah hukum yang berlaku. Selain itu BP Batam berupaya untuk memberi pemahaman kepada media apa yang sesungguhnya terjadi, agar pemberitaan yang diliput oleh media sesuai dengan fakta yang terjadi di lapangan, serta disampaikan juga informasi tentang suatu kebijakan yang diambil oleh BP Batam karena apa yang menjadi pemberitaan tersebut selalu sampai cakupan internasional.

2. Investor

Meningkatkan program pemeliharaan dan pembagunan sarana \& prasarana untuk menunjang kegiatan investasi. Dengan percayanya investor kepada Batam maka diharapkan nama BP Batam akan semakin naik. Selain itu juga BP Batam berupaya menyebarkan informasi mengenai kegiatan, kebijakan ataupun kerja sama yang dilakukan BP Batam telah melakukan kerja sama dengan 11 media local, menyediakan informasi BP Batam di KBRI (Kedutaan Besar Republik Indonesia) di luar negeri secara menyeluruh dan jelas, jadi ketika investor dari luar menanyakan informasi mengenai BP Batam, KBRI 
sudah dapat menyediakan informasi yang dibutuhkan dan mengadakan Business Gathering untuk menerima aspirasi dari investor.

Agar mendapatkan kepercayaan dari investor BP Batam juga akan mengundang narasumber dari investor yang telah sukses melakukan investasinya di Batam di dalam kegiatan business gathering. Dimana narasumber tersebut lebih mudah dipercaya karena sebagai pihak ketiga yang memberikan testimoninya dan mempunyai latar belakang yang sama dengan para investor. BP Batam juga mengundang para investor untuk mengunjungi Batam, melihat bagaimana kondisi Batam yang sudah kondusif, dan menjelaskan bahwa demo di Batam hanya terjadi pada saat-saat tertentu, dan saat ini sudah tidak ada pertikaian lagi. BP Batam ingin menjelaskan bahwa situasi saat ini sudah nyaman, dan aman sehingga investor pun sudah menganggap bahwa demo adalah hal yang wajar dan dan merupakan bagian dari proses pembelajaran demokrasi.

3. Pemerintah

BP Batam dalam melakukan komunikasi dengan pemerintah dengan menyalurkan masukan, aspirasi yang diberikan oleh investor dan calon investor ke BP Batam. Proses peneriman masukan itu biasanya melalui business gathering yang diadakan oleh unit kerja Marketing. Dikarenakan Pemerintah selalu berganti setiap lima tahun sekali, BP Batam pun bertugas untuk memperkenalkan kembali tugas dan fungsi BP Batam kepada Pemerintahan yang saat ini menjabat, cara yang dilakukan adalah mengadakan One Day Seminar di suatu kementrian dan di dalam seminar tersebut dijelaskan Road Map BP Batam selama lima tahun kedepan, pencapaian yang telah berhasil dilaksanakan dan juga untuk menjalin hubungan dengan pejabat di Kementrian tersebut, serta membantu Dinas Tenaga Kerja Pemerintahan Kota Batam untuk menyelesaikannya untuk memberkan pemahaman bahwa semua pihak harus saling sama-sama menjaga ketertiban iklim investasi di Batam.

4. Masyarakat

BP Batam bertindak sebagai supporter dari stakeholder ini untuk melaporkan keluhan masyarakat kepada pemerintah, dan membuat pemerintah mengerti. Mereka juga menerima kunjungan tamu dari Mahasiswa, memberikan bantuan-bantuan oleh BP Batam sesuai dengan apa yang dibutuhkan oleh masyarakat itu di wilayah tersebut. BP Batam juga berusaha memberi penjelasan melalui media online dan offline kepada masyarakat bahwa Batam hidup dari kegiatan investasi ini, jadi jika terjadi suatu kondisi yang berimbas terhadap kekondusifan situasi investasi di Batam, maka mau tidak mau akan berimbas kepada masyarakat itu sendiri menurut beliau. Bapak Badrul berusaha memberikan pemahaman kepada masyarakat mengenai pemahaman dari tugas dan wewenang BP Batam sendiri, apa visi dan misi yang diemban BP Batam, dan kegiatan BP Batam kedepannya.

5. Organisasi Terkait 
Memasuki naungan asosiai Kehumasan seperti Bakohumas dan Perhumas

6. Demonstran

Kasie Humas BP Batam dalam penanganan isu demonstrasi kepada para demosntran, proses melayani keluhan demonstran diterima di ruang Humas BP Batam, pada saat pertemuan tersebut BP Batam meminta perwakilan dari demonstran berkisar antara 5-10 orang. Ketika perwakilan demonstran tersebut dipanggil, pihak BP Batam akan menyerahkan daftar absen, di dalam daftar absen tersebut ada baris nomor telepon untuk diisi, dari sanalah dijalin hubungan pertemanan. Dengan menjalin hubungan tersebut BP Batam ingin mengubah pola pikir agar lebih maju pada demonstran yang hadir.

7. Unit Kerja (Internal)

Tahapan yang terjadi adalah ketika pihak humas BP Batam mendapatkan informasi isu demonstrasi dari pihak yang akan demonstransi, maka unit kerja Humas akan mencari tahu titik permasalahan yang terjadi di lapangan, setelah itu diadakan komunikasi dengan pihak yang akan mengadakan demonstrasi tersebut, dan unit kerja humas melaporkan permasalahan tersebut kepada unit kerja lain yang terkait. Posisi humas di sini siap mendampingi unit terkait untuk mendampingi unit kerja terkait menemui demonstran. Lalu dilanjutkan dengan penjelasahan strategi penyelesaian oleh unit yang bersangkutan, dan menjelaskan akar permasalahan. Hal ini dilakukan sebelum proses demonstrasi berlangsung. Setelah terjadi pertemuan dengan perwakilan demonstran, unit kerja humas akan melaporkan kepada pimpinan (ketua BP Batam), setelag dilaporkan, pimpinan akan memberikan petunjuk, solusi alternatif yang disampaikan, tapi biasanya pimpinan akan meminta pertimbangan strategi dari unit kerja humas untuk proses penanganan yang terbaik sebelum mengambil keputusan. Pada saat hari $\mathrm{H}$ demonstrasi berlangsung, humas menghubungi pihak keamanan untuk mem-back up proses terjadinya komunikasi pada saat demonstrasi mulai dari pihak Direktorat Pengamanan BP Batam dan kepolisian. Pada saat hari $\mathrm{H}$ demonstrasi, pihak BP Batam akan menerima orang yang berkompeten diantara para demosntran, untuk melakukan hearing kembali.

BP Batam dalam kegiatan Manajemen Krisis mengenai Isu Demonstrasi di Kalangan Investor, berusaha untuk merancang pola hubungan dengan stakeholdernya agar proses pengiriman dan penerimaan pesan dilakukan dengan cara yang tepat, sehingga pesan yang masuk bisa dipahami oleh ketujuh stakeholdernya, yakni pihak media, investor, pemerintah, masyarakat, organisasi terkai, demonstran dan unit kerja internal. Adapun pola komunikasi dengan para stakeholder dapat dijabarkan sebagai berikut:

1. Pola Komunikasi kepada Media

Praktisi PR punya hubungan simbiotik dengan jurnalis. Praktisi membutuhkan akses ke media berita untuk menyebarkan gagasan, informai, atau pandangan organisasi dan klien yang 
mewakili. Jurnalis mengandalkan informasi dalam press relesase untuk artikel yang pantas untuk diberitakan dikomunitas mereka. Akan tetapi, jurnalis dapat memilih apakah mereka akan menggunakan informasi press release itu atau tidak, atau apakah akan menggunaanakan wawancara dengan orang tertentu, atau mengirim surat kepada editor. Bahkan pernyataan komersial juga mendapat perlindungan yang berarti bahwa perusahaan media massa punya pilihan untuk mempublikasikan suatu kategori iklan tertentu atau tidak. (Center and Broom,Cutlip 2009:174)

Setiap krisis yang berdampak luas pada masyarakat-cenderung menjadi pemberitaan media. Bahkan, sering kali terjadi perkembangan krisis yang semula kecil, tersebar luas dan menjadi besarkarena efek pemberitaan media. Media massa mempunyai kemampuan diseminasi informasi secara serentak, repetisis, dan simultan yang membuat media mempunyai kekuatan dalam membentuk opini. Media massa adalah representasi publi untuk memperoleh informasi karenanya, diminta atau tidak, media (wartawan) akan mengerjar informasi langsung dari Public Relations. (Kriyantono, 2012:202)

Cara Humas BP Batam dalam berkomunikasi dengan media secara umum sudah cukup bagus dengan langsung memberi informasi secepatnya kepada media pada saat isu krisis mencuat ke permukaan. Dan selain itu BP Batam juga menjelaskan tindakan apa yang sdah dilakukan BP Batam untuk meminimalkan dampak krisis. Selain itu Humas BP Batam juga memonitoring berita-berita media, dan jika tejadi salah pemberitaan pun BP Batam langsung melakukan klarifikasi untuk menyampaikan informasi yang benar dan akurat.

2. Pola Komunikasi kepada Investor Hubungan Invesor adalah bagian dari PR perusahaan dalam perusahaan korporat yang membangun dan menjaga hubungan yang bermanfaat dan saling menguntungkan dengan shareholder dan pihak lain di dalam komunitas keuangan dalam rangka memaksimalkan nilai pasar. (Center and Broom,Cutlip 2009:25)

Spesialis hubungan investor selalu memberikan informasi kepada pemegang saham dan loyal kepada perusahaan dalam rangka mempertahankan nilai saham yang layak. Pekerjaan mereka antara lain meneliti tren pasar, menyediakan informasi kepada publik finansial, memberi saran menajemen, dan merespons permintaan informasi keuangan. Laporan tahunan dan laporan caturwulan, laporan pendapatan melalui e-mail, dan link homepage ke informasi finansial, adalah cara-cara yang dipakai untuk menyebarkan informasi kepada aalis, investor, dan pers finansial. (Center and Broom, Cutlip 2009:25)

Pelayanan BP Batam kepada pihak investor di dalam kegiatan Hubungan Investor ketika menangani isu demonstrasi secara umum telah berlangsung baik. Informasi-informasi yang dibutuhkan oleh investor telah terpenuhi dengan cukup baik, dan hal itu dilakukan dalam bentuk meningkatkan sarana dan prasarana yang dibutuhkan oleh Investor untuk menjalankan usahanya, meningkatkan keamanan bagi investor dengan berkoordinasi dengan Kapolda dan TNI, menyalurkan aspirasi demonstran kepada Pemerintah, menyebarkan informasi mengenai demonstrasi kepada media agar pihak investor juga mengetahuinya. Dan 
untuk calon investor lainnya yang berada di luar negeri, BP Batam telah menjelaskan isu demonstrasi yang terjadi di Batam kepada KBRI yang berada di luar negeri, jadi calon investor yang berada di luar negeri dapat menerima informasi yang tepat mengenai Batam. Selain itu untuk menghindari perasaan cemas investor mengenai isu demonstrasi ketika berinvestasi di Batam, di dalam setiap pertemuan dalam business gathering $\mathrm{BP}$ Batam akan membawa success story, yakni investor yang telah lama berada di Batam. Selain itu BP Batam untuk menangani isu demonstrasi kepada invesor juga melayani kunjungan investor yang datang secara personal yang ingin melihat kondisi Batam.

3. Pola Komunikasi kepada Pemerintah

Dalam kegiatan PR, pemerintah dianggap penting bukan saja karena pemerintah adalah pengatur negara dan pembuat keputusan penting, tetapi lebih dari itu, pemerintah terdiri dari orang-orang yang mempunyai pengaruh yang sangat besar bagi masyarakat dan kegiatan bisnis. Pemerintah Pusat, Provinsi, atau Walikota Madya, dewasa ini mempunyai pengaruh yang besar terhadap industri besar maupun kecil, mulai dari industri pertanian, elektronik, tekstil, jasa, transportasi sampai pada energi dan industri untuk ekspor. (Kasali, 1999:117)

Karena hal di ataslah BP Batam sering melakukan pendekatan kepada Pemerintah. Walaupun yang melakukan lobbying kepada Pemerintah melalui pihakpihak dari BP Batam sendiri bukan dari mantan orang pemerintahan seperti yang kebanyakan terjadi di Amerika Serikat. Tujuan dari melakukan pendekatan kepada Pemeritah ini adalah untuk melobi pemerintah yang mempunyai pengaruh besar di dalam dunia industri salah satunya dengan memengaruhi undang-undang yang berdampak pada ekonomi rakyat dan pelaksanaannya. Walaupun belum secara keseluruhan tugas dari goverment relations dilaksanakan, BP Batam berusaha memberikan pemahaman kepada Pemerintah mengenai kelembagaan dari BP Batam sendiri. Kepada Pemerintah BP Batam juga menyalurkan aspirasi-aspirasi yang dilaporkan investor kepada BP Batam. Selain melakukan pendekatan, BP Batam pun juga membantu Disnaker di dalam permasalahan penanganan demonstrasi ini.

4. Pola Komunikasi kepada Masyarakat

Komunitas lokal adalah masyarakat yang bermukim atau mencari nafkah di sekitar pabrik, kantor, gudang, tempat pelatihan, tempat peristirahatan, atau di sekitar aset tetap perusahaan lainnya. Dalam pelaksanaan fungsi PR, komunitas lokal dipandang sebagai suatu kesatuan dengan perusahaan yang memberi manfaat timbal balik. (Kasali, 1999:127)

Peran Humas BP Batam dalam menangani isu demonstrasi juga dilakukan kepada Masyarakat. Peran Humas BP Batam dalam menangani isu demonstrasi juga dilakukan kepada Masyarakat. BP Batam menginginkan keberadaannya memberi manfaat baik bagi masyarakat sekitar. Sering kali investor yang datang membuka usahanya ke Batam dengan menghuni lahan lama sering berhadapan dengan masyarakat yang telah tinggal di lahan tersebut. Ketika terjadi permasalahan antara pihak investor dan masyarakat, BP Batam hampir selalu turun ke lapangan untuk menyelesaikan permasalahan tersebut yang biasanya berfokus kepada uang sangu. 
Selain itu BP Batam juga bertindak sebagai tempat pengaduan ketika masyarakat kesulitan akan suatu hal, BP Batam akan menyampaikan aspirasi atau keluhan tersebut kepada Pemerintah. Selain itu BP Batam juga berpatisipasi di dalam kehidupan masyarakat dengan memberikan bantuan yang dibutuhkan masyarakat.

5. Pola Komunikasi kepada
Organisasi Terkait
Pertumbuhan asosiasi profesional
merefleksikan usaha serius yang dilakukan oleh banyak praktisi untuk menaikkan status dan meningkatkan kompetensi fungsi PR. Meskipun asosiasi-asosiasi ini hanya sebagain kecil dari mereka yang bekerja di bidang PR, asosiasi itu punya pengaruh besar melalui publikasi, konferensi, seminar, program penghargaaan, dan advokasi untuk praktik PR. Organisaasiorganiasi ini bersifat internasional, nasional, regional, dan ada yang dikhususkan berdasarkan area praktik seperti praktik PR di bidang kesehatan, agrikultur, atau hubungan finansial. (Center and Broom,Cutlip 2009:153)

BP Batam juga memasuki naungan asosiai Kehumasan seperti Bakohumas dan Perhumas. Salah satu bentuk kerja sama yang dilakukan BP Batam dengan asosiasi kehumasan tersebut adalah pihak Bakohumas memberikan presentasi mengenai "Menghadapi Asean Community 2015" di dalam presentasi itu dijelaskan apa saja yang harus dilakukan Humas ketika Asean Community terjadi. Dengan memasuki naungan asosiasi kehumasan BP Batam tidak tertinggal informasi yang nantinya berpengaruh ke BP Batam sendiri.

6. Pola Komunikasi kepada Demonstran
Menurut The Issue Management Council, jika terjadi gap atau perbedaan antara harapan publik dengan kebijakan, operasional, produk atau komitment organisasi tehadap publiknya, maka disitulah muncul isu. (Galloway \& Kwansah-Aidoo, 2005; Regester \& Larkin, 2008 dalam Kriyantono, 2011:152)

Untuk menyelesaikan gap yang terjadi antara investor dengan pekerjanya, BP Batam berusaha menampuang aspirasi pekerja cara itu dilakukan melalui hubungan pertemanan dan pertemuan langsung dengan demonstran. Setelah itu pihak BP Batam akan melakukan negosiasi antara investor dan pekerja dan mencari jalan tengahnya.

7. Pola Komunikasi kepada Unit Kerja (Internal)

Ketika para praktisi mengambil peran sebagai pakar/ahli, orang lain menganggap mereka sebagai otoritas dalam persoalan PR dan solusinya. Manajemen puncak menyerahkan PR di tangan para ahli dan manajemen biasanya mengambil peran pasif saja. Praktisi yang beroperasi sebagai praktisi pakar bertugas mendefinisikan problem, mengembangkan program, dan bertanggung jawab penuh atas implementasinya. Manajer lainnya mungkin ingin membuat PR sebagai satu-satunya pihak yang bertanggung jawab sehingga mereka bisa menjalankan bisnis seperti biasanya dengan berasumsi bahwa segala sesuatu akan dibereskan oleh "pakar-pakar PR.” (Center and Broom,Cutlip 2009:46)

Begitu juga yang terjadi di BP Batam, dalam pola komunikasi kepada Unit Kerja, unit kerja Humas BP Batam sering sekali langsung diturunkan ketika isu demonstrasi terjadi. Unit kerja Humas diharapkan untuk membereskan isu 
demonstrasi atau dianggap sebagai pihak yang menentukan cara penyelesaian permasalaha isu demonstrasi. Tugas unit kerja Humas BP Batam antara lain adalah mengidentifikasi, menganalisia penyebab isu tersebut dan melaporkannya kepada pimpinan. Dari pimpinan masalah diserahkan kepada unit terkat untuk diselesaikan. Humas membantu unit kerja terkait untuk memberikan penjelasan kepada demonstran.

\section{KESIMPULAN}

Berdasarkan dari hasil dan pembahasan yang telah diuraikan di atas, maka diperoleh simpulan mengenai pola komunikasi yang dilakukan Manajemen Badan Pengusahaan Kawasan Perdagangan dan Pelabuhan Bebas Batam untuk menanggulangi Isu Demonstrasi dalam kegiatan Investor Relations, adalah sebagai berikut:

1. Pola komunikasi yang dilakukan Badan Pengusahaan Kawasan Perdagangan dan Pelabuhan Bebas Batam untuk menanggulangi Isu Demonstrasi dalam kegiatan Investor Relations adalah melakukan komunikasi ke-tujuh publik baik internal maupun eksternal, yaitu Media, Investor, Pemerintah, Masyarakat, Organisasi Terkait, Demonstran, dan Unit Kerja (Internal).

2. Kendala yang dihadapi Badan Pengusahaan Kawasan Perdagangan dan Pelabuhan Bebas Batam dalam menanggulangi Isu Demonstrasi dalam kegiatan Investor Relations adalah: Kendala Internal: (1) Tekanan dari Pimpinan; (2) Kurang luasnya jaringan koneksi yang dimiliki sehingga ketika terjadi demonstrasi sulit untuk mengambil hati penduduk sekitar; (3) Koordinasi di dalam internal BP Batam terhadap sesama unit kerja lain masih dinilai kurang, terkadang pihak yang dibutuhkan sedang pergi dinas keluar kota; (4) Anggaran yang dimiliki oleh BP Batam masih terbilang cukup; (5) Oknum dari dalam BP Batam sendiri yang membocorkan informasi yang tidak benar; (6)Permasalahan teknis, karena begitu banyaknya isu yang berkembang, akhirnya unit kerja humas merasa kewalahan dikarenakan sumber daya manusia yang terbatas, dan tugas fungsi dan pokok humas yang juga tidak sedikit dalam pelaksanaan kesehariannya. Kendala Eksternal: (1) Tekanan dari Investor; (2) Tekanan dari Masyarakat; (3) Jarangnya publik yang mengunjungi website BP Batam sehingga menyebabkan penyebaran informasi masih bergantung pada media massa; (4) Di satu sisi permasalah terkadang tak kunjung selesai karena terkadang pihak yang bermasalah tidak mau menerima solusi yang telah di berikan; (5) Demonstrasi yang terjadi tidaklah murni namun dinodai dengan tujuan politik, ataupun tujuan-tujuan kepentingan sekelompok orang; (6) Oknum yang memanfaatkan situasi.

Sedangkan saran ajukan berdasarkan hasil penelitian ini antara lain adalah:

1. Sebaiknya BP Batam lebih aktif dalam melakukan pencegahan demonstrasi dengan cara mengundang delegasidelegasi dari serikat buruh untuk bermusyawarah bersama sehingga 
kegiatan demonstrasi tidak sampai terjadi

2. Sebaiknya BP Batam lebih aktif dalam usaha menangani isu demonstrasi dengan cara membentuk tim krisis atau crisis center yang sigap untuk menangani krisis agar ketika krisis terjadi sudah siap menghapinya sehingga proses penanganan krisis menjadi lebih lancar.

\section{DAFTAR PUSTAKA}

Center and Broom,Cutlip. (2009). Effective Public Relations. Jakarta: Kencana Prenada Media Group

Kasali, Rhenald. (1999). Manajemen Public Relations Kosep dan Aplikasinya di Indonesia. Jakarta: Percetakan PT Anem Kosong Anem.
Kretarto, A. (2001). Investor Relations. Jakarta IKAPI.

Kriyantono, Rachmat. (2012). Public Relations \& Crisis Management. Jakarta: Kencana Predana Media Group

Moleong, Lexy J. (2013) Metode Penelitian Kualitatif Edisi Revisi. Bandung: PT Remaja Rosdakarya

Muhammad, Arni. (2008). Komunikasi Organisasi, Jakarta: Bumi Aksara

Nova, Firsan. (2011). Crisis Public Relations. Jakarta: PR RajaGrafindo Persada 

